\title{
The occurrence of three species of the genus Oscheius Andrássy, 1976 (Nematoda: Rhabditida) in Iran
}

\author{
Ahmad Valizadeh ${ }^{1}$, Shila Goldasteh ${ }^{1 *}$, Zahra Rafiei-Karahroodi $^{1}$, Majid Pedram $^{2}$ \\ ${ }^{1}$ Department of Entomology, Arak Branch, Islamic Azad University, Arak, Iran \\ ${ }^{2}$ Department of Plant Pathology, Faculty of Agriculture, Tarbiat Modares University, Tehran, Iran
}

Vol. 57, No. 3: 248-255, 2017

DOI: 10.1515/jppr-2017-0035

Received: December 31, 2016

Accepted: August 28, 2017

*Corresponding address:

shilagoldasteh@yahoo.com

\begin{abstract}
Due to importance and effectiveness of some entomopathogenic or insect parasitic nematodes in controlling of agricultural pests, or pests of non-agricultural plants, a study was conducted in order to identify the species of this group of nematodes in city of Tehran. As the result, three species belonging to the genus Oscheius were recovered in association with bark samples having the bark beetle galleries. Morphological and molecular data were provided for two recently recovered species of the genus, namely O. necromenus and $O$. onirici. Molecular data were also provided for a recently recovered isolate of $O$. tipulae. All three species were recovered in association with bark samples collected from dead trees in the city of Tehran. Morphological characters and morphometric data of the two aforementioned species are in accordance with the data given in their original descriptions. One recovered individual from a small bark sample characterized by its short body length was sequenced for its $28 \mathrm{~S}$ and internal transcribed spacer (ITS) rDNA loci, and the results of BLAST search using the newly obtained partial sequences revealed that it belonged to O. tipulae. Molecular phylogenetic studies revealed recently sequenced Iranian populations of $O$. onirici and $O$. tipulae forming a clade with other isolates/populations of these species in ITS tree with maximal Bayesian posterior probability (BPP), and presently sequenced isolates of $O$. tipulae and $O$. necromenus form a clade with other isolates of these species in $28 \mathrm{~S}$ tree. The two species O. onirici and O. necromenus were reported in Iran for the first time.
\end{abstract}

Key words: Bayesian posterior probability, ITS, molecular analysis, Oscheius necromenus, Oscheius onirici, Oscheius tipulae

\section{Introduction}

The genus Oscheius was established by Andrássy (1976) with O. insectivorus (Körner, 1954) Andrássy, 1976 as its type species. The genus is in the family Rhabditidae Örley, 1880 (Andrássy 2005). According to Sudhaus (1976) and Sudhaus and Hooper (1994), species of the genus form two separate subclades. The 42 known species of the genus are clustered in two Insectivora and Dolichura groups (Tabassum et al. 2016). According to Liu et al. (2012), different types of host association are known for the species of the genus in the Insectivora group. In a recent study (Sudhaus 2016), host associations of Dolichura group members with insects were discussed. Some types of associations with insects have also been reported for Dolichura group members, like the relation of O. pheropsophi (Smart and Nguyen 1994). Sudhaus (2011) with cadavers of the bombardier beetle (Smart and Nguyen 1994). Torrini et al. (2015) reported and described the first entomopathogenic nematodes (EPN) belonging to the Dolichura group. This finding was further studied/ criticized by Campos-Herrera et al. (2015).

The genus has also some unique biological characters, making it a suitable candidate for genetic studies and a third model nematode species (Sommer 2000; Dichtel-Danjoy and Félix 2004 a, b). 
Several nematodes associated with the bark of dead or dying trees having beetle galleries or recovered from organic material in Iran have been recently described (Pedram et al. 2011, 2012; Atighi et al. 2012; Aliramaji et al. 2014a, b, 2015; Ghaemi et al. 2015; Miraeiz et al. 2015; Alvani et al. 2016). In a short report, Hassani-Kakhaki et al. (2012) reported the species O. tipulae (Lam and Webster 1971) in Iran. However, no morphological and/or morphometric data were provided for the recovered population. Occurrence of the species O. rugaoensis (Zhang et al. 2012) in Iran was reported by Darsouei et al. (2014). Just recently, Torrini et al. (2016) used molecular data of an Iranian isolate of $O$. tipulae in their phylogenetic analysis of several isolates of the species from several geographic regions. Recently, a study by Shahabi et al. (2016) was carried out on some free-living nematodes of northern Iran. During our recent samplings, some specimens belonging to three species of the genus Oscheius were recovered from the city of Tehran. The present study aims to perform morphological and molecular studies on recovered populations of two species O. necromenus (Sudhaus and Schulte 1989) and O. onirici Torrini, Mazza, Carletti, Benvenuti, Roversi, Fanelli, De Luca, Troccoli \& Tarasco, 2015 and to characterize the single individual of $O$. tipulae with its molecular data. The two former species were reported in Iran for the first time and molecular data were provided for the recovered isolate of $O$. tipulae.

\section{Materials and Methods}

\section{Sampling, extracting, mounting and taxonomy}

Wood and bark samples were collected in the city of Tehran. Nematodes were extracted from bark samples having bark beetle galleries using the tray method (Whitehead and Hemming 1965). Nematodes were heat-killed by adding boiling $4 \%$ formalin solution, transferred to anhydrous glycerin according to De Grisse (1969), mounted on permanent slides and examined using a Nikon Eclipse E600 light microscope. Photographs were taken using an Olympus DP72 digital camera attached to an Olympus BX51 microscope powered with differential interference contrast (DIC).

Morphological characters and morphometric data, given in original descriptions and the data given by Tabassum et al. (2016), were used for morphological identification.

\section{DNA extracting, PCR and sequencing}

DNA was extracted from single individuals using the proteinase K method of Soleymanzadeh et al. (2016) or according to Pedram et al. (2015). In the first method, a single nematode individual was transferred to an Eppendorf tube containing $1 \mu \mathrm{l}$ proteinase $\mathrm{K}$ (CinnaGen, Tehran) $\left(10 \mathrm{mg} \cdot \mathrm{ml}^{-1}\right)$ and $49 \mu \mathrm{l}$ of extraction buffer [worm lysis buffer, cf. Williams et al. (1992]; containing: $50 \mathrm{mM} \mathrm{KCl}, 10 \mathrm{mM}$ Tris-Cl $\mathrm{pH} 8.3$, $2.5 \mathrm{mM} \mathrm{MgCl}_{2}, 0.45 \% \mathrm{NP} 40$, and $0.45 \%$ Tween 20, frozen at $-80^{\circ} \mathrm{C}(20 \mathrm{~min})$, followed by incubation at $65^{\circ} \mathrm{C}(2 \mathrm{~h})$ and then at $95^{\circ} \mathrm{C}(10 \mathrm{~min})$. DNA samples were stored at $-20^{\circ} \mathrm{C}$ until used as polymerase chain reaction (PCR) templates.

PCR was carried out in a total volume of $30 \mu 1$ (19.2 $\mu \mathrm{l}$ distilled water, $3 \mu \mathrm{l} 10 \times$ PCR buffer, $0.6 \mu \mathrm{l}$ $10 \mathrm{mM}$ dNTP mixture, $1.2 \mu \mathrm{l} 50 \mathrm{mM} \mathrm{MgCl}{ }_{2}, 1.2 \mu \mathrm{l}$ of each primer $\left(10 \mathrm{pmol} \cdot \mu \mathrm{l}^{-1}\right), 0.6 \mu \mathrm{l}$ of Taq DNA polymerase ( 5 unit $\cdot \mu 1^{-1}$, CinnaGen, Tehran, Iran) and $3 \mu \mathrm{l}$ of DNA template). The thermal cycling program for amplifying three genomic fragments [18S rDNA, 28S rDNA D2/D3 and internal transcribed spacer (ITS)] was as follows: denaturation at $95^{\circ} \mathrm{C}$ for $4 \mathrm{~min}$, followed by 32 cycles of denaturation at $94^{\circ} \mathrm{C}$ for $30 \mathrm{~s}$, annealing at $55^{\circ} \mathrm{C}$ for $40 \mathrm{~s}$, and extension at $72^{\circ} \mathrm{C}$ for $80 \mathrm{~s}$. A final extension was performed at $72^{\circ} \mathrm{C}$ for $10 \mathrm{~min}$. Primers for amplification of $28 \mathrm{~S}$ rDNA D2/D3 were forward primer D2A (5'-ACAA GTACCGTGAGGGAAAGT-3') and reverse primer D3B (5' -TGCGAAGGAACCAGCTACTA-3') (Nunn 1992). A combination of the primers TW81 (5'-GTTTCCGTAGGTGAACCTGC-3') (forward) and AB28 (5'-ATATGCTTAAGTTCAGCGGGT-3') (reverse) (Joyce et al. 1994) and 5.8SM5 (5'-GG CGCAATGTGCATTCGA-3') (Zheng et al. 2000) were used for amplifying the ITS fragment. The PCR products were sequenced in both directions using the same primers with an ABI 3730XL sequencer (Applied Biosystems) at Macrogen (Seoul, South Korea). Newly obtained sequences of the studied species were deposited in GenBank (accession numbers: KY366261 and KY366262 for partial ITS sequences of $O$. onirici and O. tipulae and KY366263 and KY366264 for partial 28S rDAN D2/D3 sequence of $O$. tipulae and O. necromenus respectively).

\section{Phylogenetic analysis}

The newly obtained ITS and 28S rDNA D2/D3 sequences of the recovered populations were compared with those of other nematode species available in GenBank using the BLAST homology search program. The ITS rDNA sequences of 20 species/isolates of the genus Oscheius and one outgroup species (accession numbers and full species names in Fig. 1) and 27 sequences of species/isolates of 28S rDNA D2/D3 belonging to the genus Oscheius, some unidentified rhabditid taxa and one outgroup species (accession numbers and full species names in Fig. 2) were aligned using 


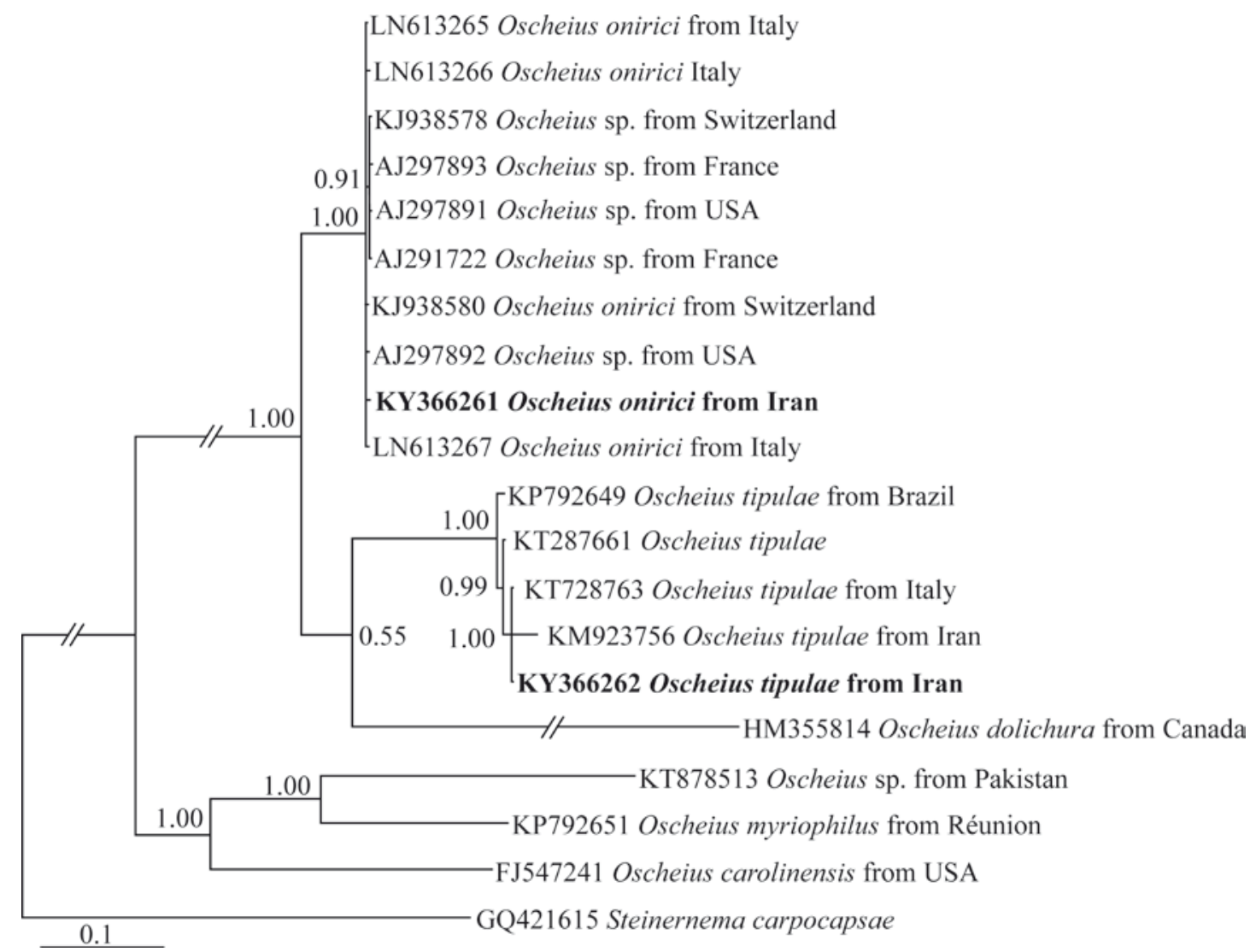

Fig. 1. Bayesian tree inferred under the GTR $+\mathrm{G}$ model using ITS sequence of Oscheius spp. Posterior probability values exceeding $50 \%$ are given on appropriate clades

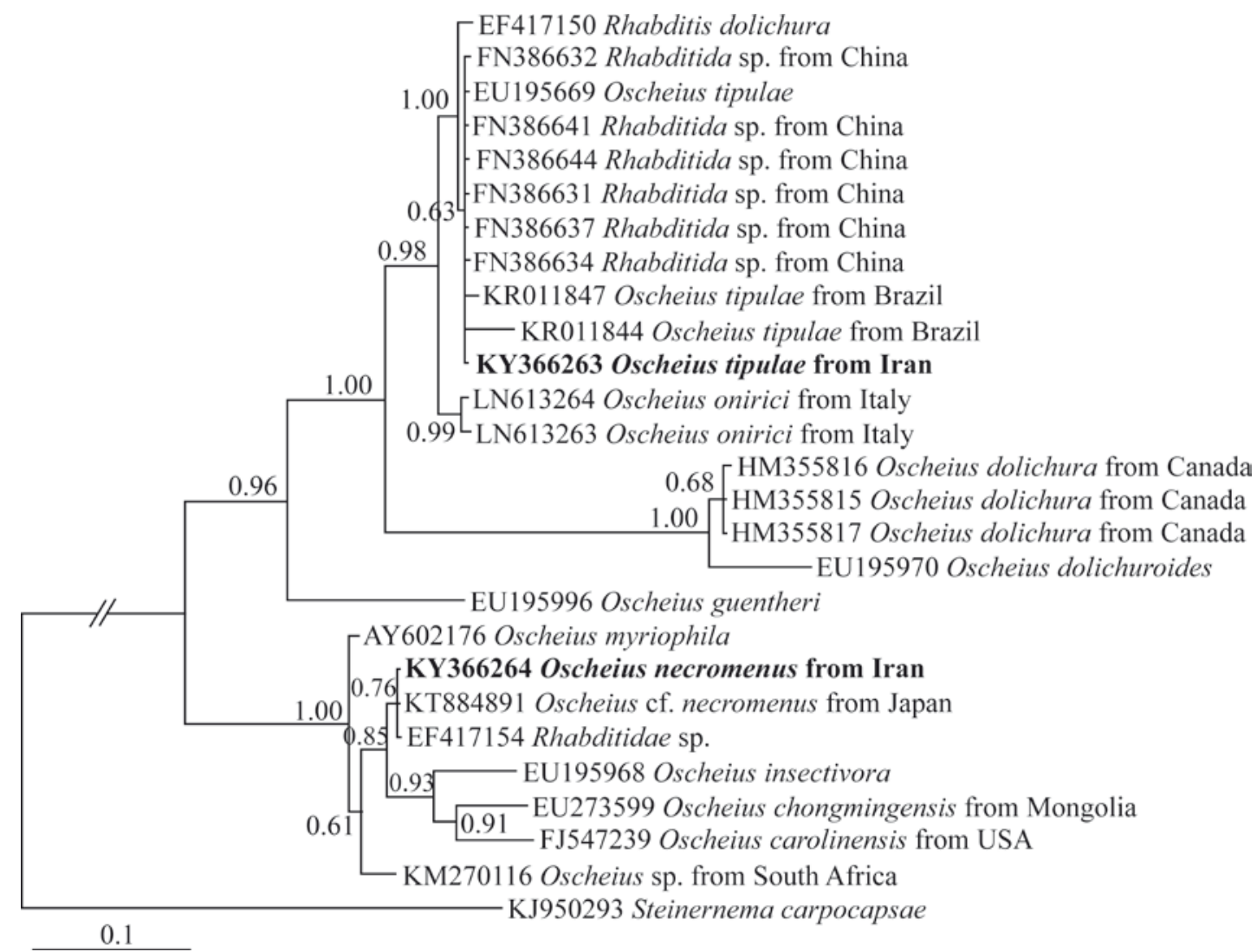

Fig. 2. Bayesian tree inferred under the HKY $+\mathrm{G}$ model using $28 \mathrm{~S}$ rDNA D2/D3 fragments of Oscheius spp. Posterior probability values exceeding $50 \%$ are given on appropriate clades 
MUSCLE (Edgar 2004) as implemented in MEGA6 (Tamura et al. 2013). The online version of Gblocks $0.91 b$ (Castresana 2000) was used to eliminate ambiguous parts of the alignment, with all three options for a less stringent selection (http://molevol.cmima.csic. es/castresana/Gblocks_server.html). The most appropriate model of nucleotide substitution was selected using the Akaike information criterion in MrModeltest 2 (Nylander 2004). The general time reversible model including gamma distribution for rates across sites $(\mathrm{GTR}+\mathrm{G})$ was selected for $28 \mathrm{~S}$ and a Hasegawa-Kishino-Yano model including gamma distribution for rates across sites $(\mathrm{HKY}+\mathrm{G})$ was selected for ITS dataset. Bayesian inference (BI) was performed using MrBayes v3.1.2 (Ronquist and Huelsenbeck 2003) running the chains for one million generations. After discarding burn-in samples, the remaining samples were retained for further analyses. The Markov chain Monte Carlo (MCMC) method within a Bayesian framework was used to estimate the posterior probabilities of the phylogenetic trees (Larget and Simon 1999) using the 50\% majority rule. Burn-in was determined upon stabilization of log likelihood using TRACER v1.5 (Drummond and Rambaut 2007). For both ITS and 28S datasets, the species Steinernema carpocapsae (Weiser, 1955) Wouts et al. (1982) was used as outgroup taxon. The resultant tree files were visualised using Dendroscope V.3.2.8 (Huson and Scornavacca 2012) and re-drawn in CoreIDRAW software version 16.

\section{Results and Discussion}

\section{Oscheius necromenus (Sudhaus and Schulte 1989)}

This species was recovered from bark samples of dead grapevine trees in the Yaftabad region, Tehran. Morphological characters and morphometric data of this population are in full agreement with the data given in the original description of the species and the morphometric data ranges given by Tabassum et al. (2016) (Fig. 3, Table 1). This species is new for Iran's nematode fauna.

\section{Oscheius onirici Torrini, Mazza, Carletti, Benvenuti, Roversi, Fanelli, De Luca, Troccoli \& Tarasco, 2015}

The presently studied population of this species was in association with galleries on bark samples of $\mathrm{Pi}$ nus eldarica trees in the Lavizan region, Tehran. No morphological or morphometric differences were observed between the presently studied population and the original data given by Torrini et al. (2015) (Fig. 4,
Table 1. Morphometric data of two species Oscheius oniric and $O$. necromenus recovered in the present study. All measurements are in $\mu \mathrm{m}$ and in the form mean $\pm \mathrm{SD}$ (range)

\begin{tabular}{|c|c|c|}
\hline Measurements & O. necromenus & O. onirici \\
\hline $\mathrm{N}$ & 10 우우 & 8 우우 \\
\hline L & $\begin{array}{c}1189 \pm 193 \\
(958-1580)\end{array}$ & $\begin{array}{c}728.5 \pm 102.0 \\
(506-842)\end{array}$ \\
\hline a & $\begin{array}{c}17.2 \pm 3.2 \\
(13.6-24.8)\end{array}$ & $\begin{array}{c}30.4 \pm 14.3 \\
(16.2-49.5)\end{array}$ \\
\hline b & $\begin{array}{c}6.8 \pm 1.1 \\
(5.1-8.5)\end{array}$ & $\begin{array}{c}5.8 \pm 0.9 \\
(4.4-6.7)\end{array}$ \\
\hline c & $\begin{array}{c}11.3 \pm 2.7 \\
(8.0-15.5)\end{array}$ & $\begin{array}{c}9.9 \pm 1.2 \\
(8.1-11.5)\end{array}$ \\
\hline$c^{\prime}$ & $\begin{array}{c}4.7 \pm 1.5 \\
(2.4-7.0)\end{array}$ & $\begin{array}{c}5.3 \pm 1.2 \\
(3.9-6.7)\end{array}$ \\
\hline V & $\begin{array}{c}49.5 \pm 3.5 \\
(41.4-523)\end{array}$ & $\begin{array}{c}49.0 \pm 1.1 \\
(47.6-5032)\end{array}$ \\
\hline Stoma & $\begin{array}{c}15 \pm 2 \\
(13-18)\end{array}$ & $\begin{array}{c}15.0 \pm 1.2 \\
(13-17)\end{array}$ \\
\hline Pharynx & $\begin{array}{c}177.0 \pm 17.5 \\
(143-193)\end{array}$ & $\begin{array}{c}125 \pm 12 \\
(113-152)\end{array}$ \\
\hline Head-vulva & $\begin{array}{c}587.5 \pm 104.5 \\
(467-817)\end{array}$ & $\begin{array}{c}373.0 \pm 29.5 \\
(330-423)\end{array}$ \\
\hline Head-anus & $\begin{array}{c}1081 \pm 199 \\
(853-1478)\end{array}$ & $\begin{array}{c}682 \pm 48 \\
(608-755)\end{array}$ \\
\hline Body width & $\begin{array}{c}72 \pm 21 \\
(49-116)\end{array}$ & $\begin{array}{c}28.5 \pm 12.5 \\
(15-48)\end{array}$ \\
\hline Anal body width & $\begin{array}{c}25.0 \pm 7.8 \\
(16-42)\end{array}$ & $\begin{array}{c}14.5 \pm 2.7 \\
(12-20)\end{array}$ \\
\hline Tail & $\begin{array}{c}108 \pm 13.5 \\
(91-127)\end{array}$ & $\begin{array}{c}78.0 \pm 10.3 \\
(61-88)\end{array}$ \\
\hline
\end{tabular}

$\mathrm{N}$ - number of individuals, $\mathrm{L}$ - body length, a - body length/body width, b- bodylength/length of pharynx, c-bodylength/tail length, $c^{\prime}$ - tail length/ body width at anus level, $\mathrm{V}-$ anterior end to vulva $\times 100 /$ body length

Table 1). This is the first report of this species occurring in Iran.

\section{Oscheius tipulae (Lam and Webster 1971)}

Only one specimen of this species was recovered (a damaged female, not suitable for rearing on Nutrient Agar plates) from a bark sample. Its small body size prompted us to sequence it for both $28 \mathrm{~S}$ rDNA D2/ D3 and ITS fragments. The results confirmed that it belongs to O. tipulae.

\section{Molecular phylogenetic relationships}

Sequencings of ITS rDNA of O. onirici and O. tipulae yielded single fragments of 495 and $754 \mathrm{nt}$, respectively. The size of $28 \mathrm{~S}$ rDNA D2/D3 fragments of O. necromenus and O. tipulae was 610 and 599 nt. 

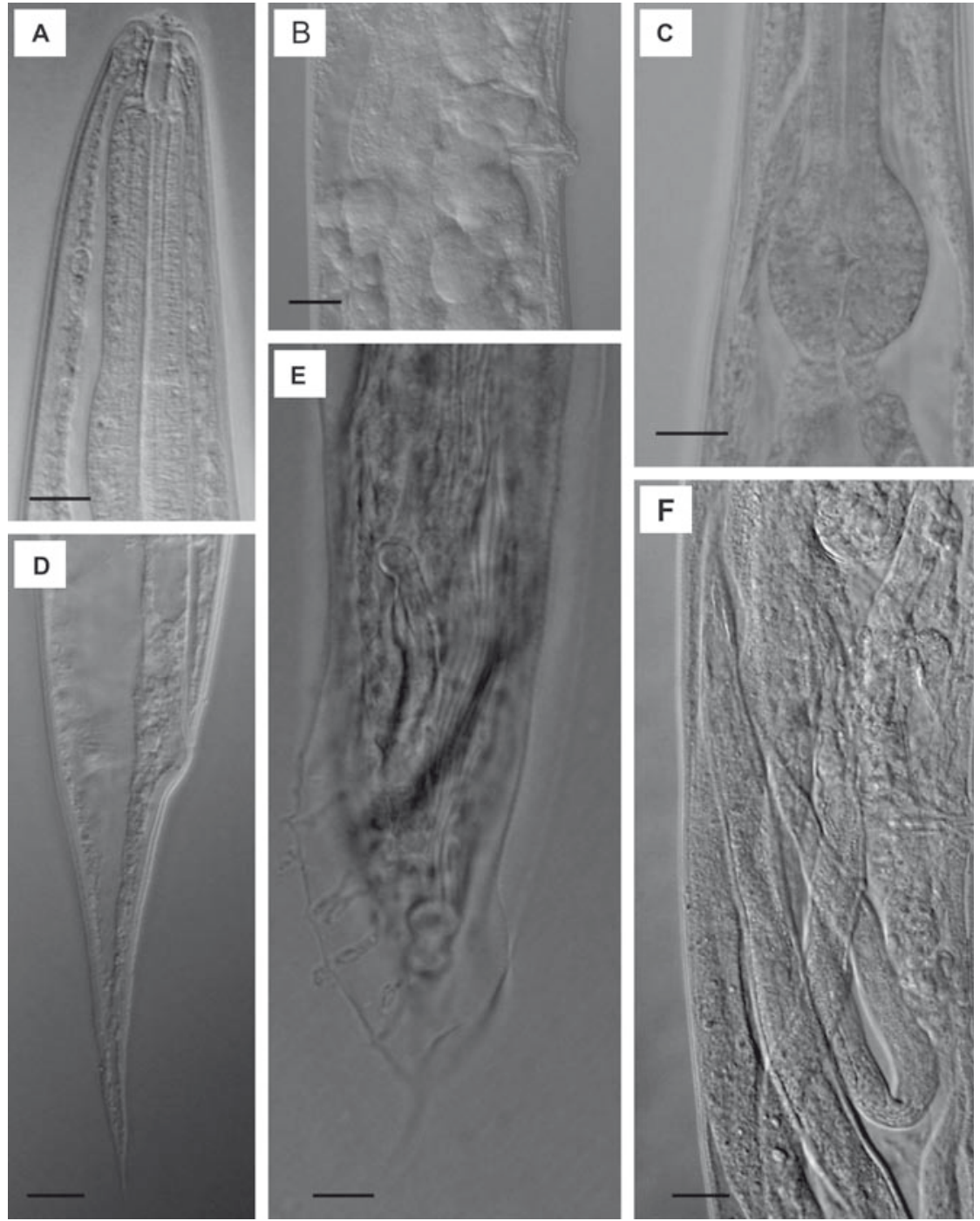

Fig. 3. Iranian population of Oscheius necromenus; A-D, F - female, E - male: A - anterior region, $\mathrm{B}$ - vagina, $\mathrm{C}$ - pharyngeal bulb, $\mathrm{D}$ - tail, $\mathrm{E}$ - cloacal region, $\mathrm{F}$ - juveniles inside the body of the female (scale bars: $A, C, D=10 \mu \mathrm{m}$, the rest $=20 \mu \mathrm{m}$ )
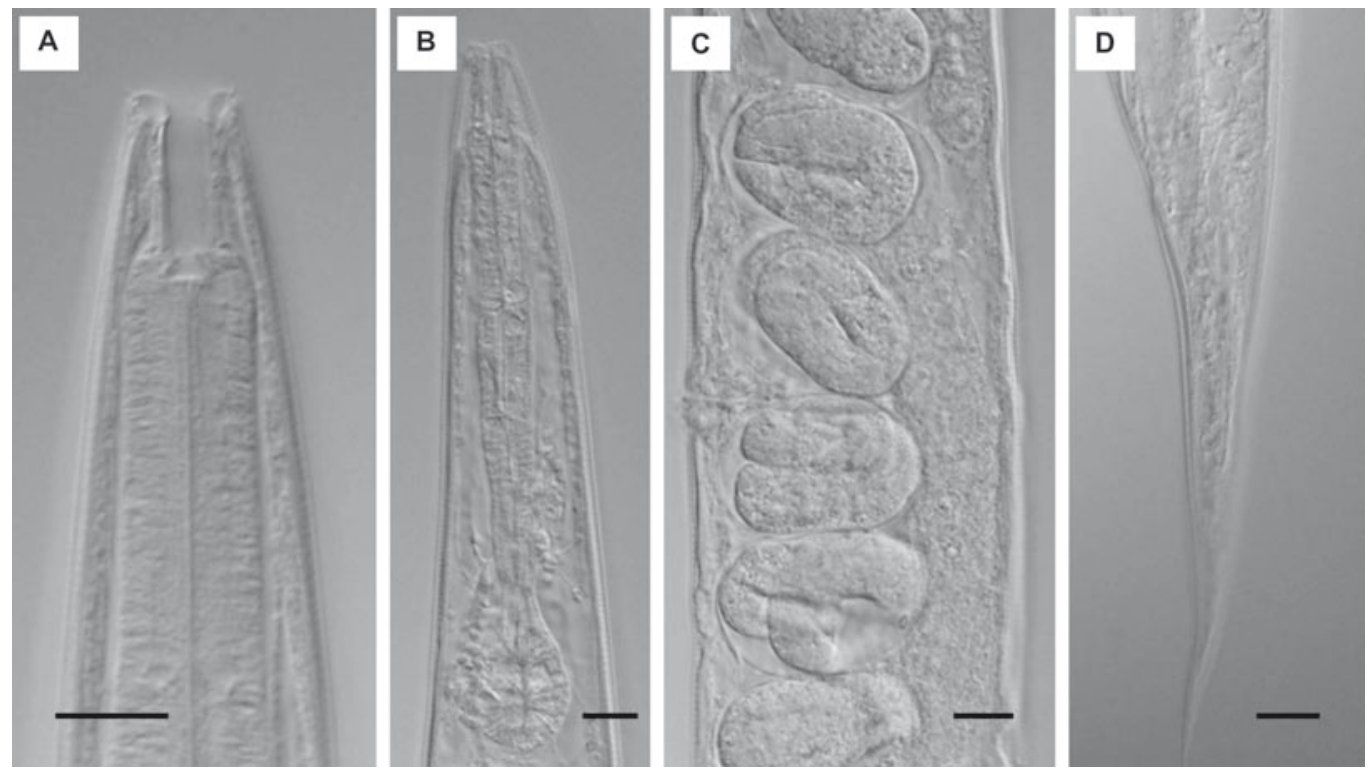

Fig. 4. Iranian population of Oscheius onirici - female: A - anterior region, B - pharynx, C - vulval region, $\mathrm{D}$ - tail (scale bars $=10 \mu \mathrm{m})$ 
Blast search using newly obtained ITS and 28S rDNA sequences of the sequenced isolate of $O$. tipulae revealed that the ITS sequence has $99-100 \%$ identity with the available ITS sequences of the species in the database. Blast search using $28 \mathrm{~S}$ rDNA D2/D3 fragment yielded the same result. Blast search using partial ITS sequence of Iranian isolate of O. onirici revealed that the sequence has $100 \%$ identity with the ITS sequences of the species provided in its original description and sequences of other isolates deposited in GenBank. The 28S rDNA D2/ D3 sequence of O. necromenus had $100 \%$ identity with an isolate of the species deposited in the database (accession number: KT884891). For reconstructing the ITS tree, a total number of 20 sequences of species/isolates of the genus Oscheius and one outgroup taxon (Steinernema carpocapsae, GQ421615) were used. Figure 4 presents the tree inferred using the aforementioned dataset. In this tree, the Iranian isolate of $O$. tipulae formed a clade with other isolates of the species with maximal BPP. The Iranian isolate of $O$. onirici also formed a fully supported monophyletic group with other isolates of the species. In $28 \mathrm{~S}$ tree, sequences of 27 species/isolates of Oscheius spp. including one outgroup species (S. carpocapsae, KJ950293) were used. The Iranian isolate of the species that was sequenced in the present study formed a clade with other isolates of the species and some other unidentified species/isolates (most probably belonging to O. tipulae). The Iranian isolate of the species $O$. necromenus was recovered and sequenced while the present study also formed a clade with a sequence labelled as $O$. cf. necromenus (accession number: KT884891) number and one unidentified isolate, probably belonging to this species.

In this study three species belonging to the genus Oscheious were recovered from the city of Tehran. From the recovered species, the species $O$. necromenus belongs to the Insectivora group, and two other species belong to the Dolichura group. As Campos-Herrera et al. (2015) cited, there are true entomopathogenic forms in the former group, making them suitable biocontrol agents against soil-dwelling pests, harmful for agricultural crops and natural ecosystems. The entomopathogenicity of the species in the Dolichura group however needs further studies for confirmation (Campos-Herrera et al. 2015). Recovery of three species of the genus from Tehran suggests that it is possible to have higher species diversity of the genus Oscheius in Iran, and needs further research and extensive samplings. The potential of some tentative endemic entomopathogenic forms in controlling endemic agricultural pests is another issue, and could be tested using endemic entomopathogenic strains.

In the present study, two species $O$. onirici and O. necromenus were characterized with their morphological and molecular data, however, the species
O. tipulae was successfully characterized with molecular sequences of two genomic fragments. The usefulness of molecular data to distinguish this species from its closely related forms has already been documented by Félix et al. (2001).

\section{Acknowledgements}

We appreciate the kind help of Prof. Marie-Anne Félix (Institute of Biology of the Ecole Normale Supérieure) and Dr. Raquel Campos-Herrera (Universidade do Algarve, Portugal).

\section{References}

Aliramaji F., Pourjam E., Atighi M.R., Pedram M. 2014a. Devibursaphelenchus kheirii sp. n. (Nematoda: Ektaphelenchinae) from Iran with remarks on Devibursaphelenchus Kakuliya, 1967. Nematology 16 (9): 1069-1078. DOI: https://doi.org/10.1163/15685411-00002833

Aliramaji F., Pourjam E., Atighi M.R., Roshan-Bakhsh A., Ye W., Pedram M. 2014b. Description of Ektaphelenchoides poinari sp. n. (Nematoda: Ektaphelenchinae) from Iran with compendium of the valid species of the genus Ektaphelenchoides Baujard, 1984. Russian Journal of Nematology 22: 11-22.

Aliramaji F., Pourjam E., Karegar A., Atighi M.R., Pedram M. 2015. Description of Ektaphelenchoides caspiensis n. sp. (Nematoda: Ektaphelenchinae) from Iran. Nematology 17 (2): 169-177. DOI: https://doi.org/10.1163/1568541100002862

Alvani S., Mahdikhani-Moghadam E., Giblin-Davis R.M., Pedram M. 2016. Description of Ektaphelenchus berbericus n. sp. (Rhabditida: Ektaphelenchinae) from eastern Iran. Nematology 18 (9): 1063-1077. DOI: https://doi. org/10.1163/15685411-00003015

Andrássy I. 1976. Evolution as a Basis for the Systematization of Nematodes. Pitman Publishing, Budapest, London, San Fransisco, $288 \mathrm{pp}$.

Andrássy I. 2005. Free Living Nematodes of Hungary. Vol. 1: Nematoda errantia. Hungarian Natural History Museum, Budapest, $495 \mathrm{pp}$

Atighi M.R., Pourjam E., Pedram M., Ye W., Robbins R.T. 2012. Molecular and morphological characterization of Ektaphelenchoides kelardashtensis sp. n. (Nematoda: Ektaphelenchinae) from northern Iran. Russian Journal of Nematology 21:23-30.

Campos-Herrera R., Půža V., Jaffuel G., Blanco-Pérez R., Cepulyte-Rakauskiene R., Turlings T. 2015. Unraveling the intraguild competition between Oscheius spp. nematodes and entomopathogenic nematodes: implications for their natural distribution in Swiss agricultural soils. Journal of Invertebrate Pathology 132: 216-227. DOI: https://doi. org/10.1016/j.jip.2015.10.007

Castresana J. 2000. Selection of conserved blocks from multiple alignments for their use in phylogenetic analysis. Molecular Biology and Evolution 17 (4): 540-552. DOI: https://doi. org/10.1093/oxfordjournals.molbev.a026334

Darsouei R., Karimi J., Shokoohi E. 2014. Oscheius rugaoensis and Pristionchus maupasi, two new records of entomophilic nematodes from Iran. Russian Journal of Nematology 22 (2): 141-55.

De Grisse A.T. 1969. Redescription ou modifications de quelques techniques utilisées dans létude des nematodes phytoparasitaires. [Redescription or modification of some techniques used in the study of phytoparasitic nematodes]. Mededelingen Faculteit Landbouwwetenschappen Rijksuniversiteit Gent 34: 351-369. (in French) 
Drummond A.J., Rambaut A. 2007. BEAST: Bayesian evolutionary analysis by sampling trees. BMC Evolutionary Biology 7, 214 pp. DOI: https://doi.org/10.1186/1471-2148-7-214

Dichtel-Danjoy M.L., Félix M.A. 2004a. Phenotypic neighborhood and micro-evolvability. Trends in Genetics 20 (5): 268-276. DOI: https://doi.org/10.1016/j.tig.2004.03.010

Dichtel-Danjoy M.L., Félix M.A. 2004b. The two steps of vulval induction in Oscheius tipulae CEW1 recruit common regulators including a MEK kinase. Developmental $\mathrm{Bi}$ ology 265 (1): 113-126. DOI: https://doi.org/10.1016/j. ydbio.2003.09.010

Edgar R.C. 2004. MUSCLE: multiple sequence alignment with high accuracy and high throughput. Nucleic Acids Research 32 (5): 1792-1797. DOI: https://doi.org/10.1093/ nar/gkh340

Félix M.A., Vierstraete A., Vanfleteren J. 2001. Three biological species closely related to Rhabditis (Oscheius) pseudodolichura Körner in Osche, 1952. Journal of Nematology 33 (2-3): 104-109. PMCID: PMC2638136

Ghaemi R., Pourjam E., Álvarez-Ortega S., Pedram M., Atighi M.R. 2015. A curious nematode, Diploscapteroides persicus n. sp. (Nematoda: Rhabditida: Rhabditomorpha) from Iran with note on status of male genital papillae. Nematology 17 (9): 1045-1056. DOI: https://doi.org/10.1163/1568541100002922

Hassani-Kakhki M., Karimi J., Hosseini M., Heydari Sh. 2012. Efficacy of entomopathogenic nematodes against potato tuber moth, Phthorimaea operculella Zeller (Lep.: Gelechiidae). 20th Iranian Plant Protection Congress, Shiraz University, Shiraz, Iran, 25-28 August 2012, 987 pp.

Huson D.H., Scornavacca C. 2012. Dendroscope 3: an interactive tool for rooted phylogenetic trees and networks. Systematic Biology 61 (6): 1061-1067. DOI: https://doi. org/10.1093/sysbio/sys062

Joyce S.A., Reid A., Driver F., Curran J. 1994. Application of polymerase chain reaction (PCR) methods to identification of entomopathogenic nematodes. p. 178-187. In: "Biotechnology: Genetics of Entomopathogenic Nematode-Bacterium Complexes" (A.M. Burnell, R.U. Ehlers, J.P. Masson, eds.). Proceedings of Symposium and Workshop, St. Patrick's College, Maynooth, Co. Kildare, Ireland, Luxembourg, European Commission, DG XII.

Lam A.B.Q., Webster J.M. 1971. Morphology and biology of Panagrolaimus tipulae n. sp. (Panagrolaimidae) and Rhabditis (Rhabditella) tipulae n. sp. (Rhabditidae), from leatherjacket larvae, Tipula paludosa (Diptera: Tipulidae). Nematologica 17 (2): 201-212. DOI: https://doi. org $/ 10.1163 / 187529271 \times 00044$

Larget B., Simon D.L. 1999. Markov chain Monte Carlo algorithms for the Bayesian analysis of phylogenetic trees. Molecular Biology and Evolution 16 (6): 750-759. DOI: https:// doi.org/10.1093/oxfordjournals.molbev.a026160

Liu Q.Z., Mrácčk Z., Zhang L.J., Půža V., Dong L.M. 2012. Redescription of Oscheius chongmingensis (Nematoda: Rhabditidae) and its entomopathogenicity. Nematology 14 (2): 139-149. DOI: https://doi.org/10.1163/138855411x580777

Miraeiz E., Heydari R., Álvarez-Ortega S., Pedram M., Atighi M.R. 2015. Molecular and morphological characterization of Veleshkinema iranicum n. gen., n. sp. (Nematoda: Hexatylina, Sphaerularioidea) from Iran. Zootaxa 4000 (5): 531-546.

Nunn G.B. 1992. Nematode molecular evolution. An investigation of evolutionary patterns among nematodes based on DNA sequences. Ph.D. thesis, Nottingham, University of Nottingham, UK.

Nylander J.A. 2004. MrModeltest v2. Evolutionary Biology Centre, Uppsala University. Available on: https:/github.com/ nylander/MrModeltest2. Accessed [March 15, 2015]

Pedram M., Pourjam E., Ye W., Atighi M.R., Robbins R.T., Ryss A. 2011. Description of Bursaphelenchus mazandaranense sp. n. (Nematoda: Parasitaphelenchidae) from Iran. Russian Journal of Nematology 19: 121-129.
Pedram M., Pourjam E., Atighi M.R., Ye W., Houshmand A. 2012. Description of Ektaphelenchoides sylvestris sp. nov. (Nematoda: Ektaphelenchinae) from Iran. Annales Zoologici 62 (2): 325-329. DOI: https://doi.org/10.3161/000345412X652864

Pedram M., Pourjam E., Atighi M.R., Panahandeh Y. 2015. Further studies on soil nematode fauna in north western Iran with the description of one new species. Journal of Nematology 47 (2): 148-152. PMCID: PMC4492290

Shahabi S., Kheiri A., Rakhshandehroo F., Jamali S. 2016. Occurrence and distribution of nematodes in rice fields in Guilan province, Iran and the first record of Mylonchulus polonicus (Stefanski, 1915) Cobb, 1917 (Nematoda: Mononchina). Journal of Plant Protection Research 56 (4): 420-429. DOI: https://doi.org/10.1515/jppr-2016-0062

Ronquist F., Huelsenbeck J.P. 2003. MrBAYES 3: Bayesian phylogenetic inference under mixed models. Bioinformatics 19 (12): 1572-1574. DOI: https://doi.org/10.1093/bioinformatics/btg 180

Smart G.C. Jr, Nguyen K.B. 1994. Rhabditis (Oscheius) pheropsophi n. sp. (Rhabditida: Rhabditidae). Journal of Nematology 26 (1): 19-24. PMCID: PMC2619479

Soleymanzadeh M., Pedram M., Pourjam E., Álvarez-Ortega S. 2016. Description of Lelenchus brevislitus n. sp. (Nematoda: Tylenchidae), an example of a cryptic species from Iran and its phylogenetic relationships with other species in the family. Nematology 18 (8): 987-998. DOI: https://doi. org/10.1163/15685411-00003010

Sommer R.J. 2000. Comparative genetics: A third model nematode species. Current Biology 10 (23): 879-881. DOI: https://doi.org/10.1016/s0960-9822(00)00815-0

Sudhaus W. 1976. Vergleichende Untersuchungen zur Phylogenie, Systematik, Ökologie, Biologie und Ethologie der Rhabditidae (Nematoda). [Comparative studies on the phylogeny, systematics, ecology, biology and ethology of the Rhabditidae (Nematoda)]. Zoologica 43: 1-228. (in German)

Sudhaus W. 2011. Phylogenetic systemization and catalogue of paraphyletic "Rhabditidae" (Secernentea: Nematoda). Journal of Nematode Morphology and Systematics 14: $113-178$

Sudhaus W. 2016. The guild of saprobiontic nematodes associated with ants. Ecologica Montenegrina 7: 600-613.

Sudhaus W., Hooper D.J. 1994. Rhabditis (Oscheius) guentheri sp. n., an unusual species with reduced posterior ovary, with observations on the Dolichura and Insectivora groups (Nematoda: Rhabditidae). Nematologica 40 (1): 508-533. DOI: https://doi.org/10.1163/003525994x00391

Sudhaus W., Schulte F. 1989. Rhabditis (Rhabditis) necromena sp. n. (Nematoda: Rhabditidae) from South Australian Diplopoda with notes on its siblings $R$. myriophila Poinar, 1986 and R. caulleryi Maupas, 1919. Nematologica 35 (1): 15-24. DOI: https://doi.org/10.1163/002825989x00025

Tabassum K.A., Shahina F., Nasira K., Erum Y.I. 2016. Description of six new species of Oscheius Andrássy, 1976 (Nematoda: Rhabditida) from Pakistan with a key and diagnostic compendium to species of the genus. Pakistan Journal of Nematology 34 (2): 109-161. DOI: https://doi.org/10.18681/ pjn.v34.i02.p109

Tamura K., Stecher G., Peterson D., Filipski A., Kumar S. 2013. MEGA6: molecular evolutionary genetics analysis version 6.0. Molecular Biology and Evolution 30 (12): 2725-2729. DOI: https://doi.org/10.1093/molbev/mst197

Torrini G., Mazza G., Carletti B., Benvenuti C., Roversi P.F., Fanelli E., De Luca F., Troccoli A., Tarasco E. 2015. Oscheius onirici sp. n. (Nematoda: Rhabditidae): a new entomopathogenic nematode from an Italian cave. Zootaxa 3937 (3): 533-548. DOI: https://doi.org/10.11646/ zootaxa.3937.3.6

Torrini G., Mazza G., Strangi A., Barabaschi D., Landi S., Mori E., Menchetti M., Sposimo P., Giuliani C., Zoccola A., Lazzaro L., Ferretti G., Foggi B., Roversi P.F. 2016. Oscheius 
tipulae in Italy: evidence of an alien isolate in the Integral Natural Reserve of Montecristo Island (Tuscany). Journal of Nematology 48 (1): 8-13. DOI: https://doi.org/10.21307/ jofnem-2017-003

Whitehead A.G., Hemming J.R. 1965. A comparison of some quantitative methods of extracting small vermiform nematodes from soil. Annals of Applied Biology 55 (1): 25-38. DOI: https://doi.org/10.1111/j.1744-7348.1965.tb07864.x

Williams B.D., Schrank B., Huynh C., Shownkeen R., Waterston R.H. 1992. A genetic mapping system in Caenorhabditis elegans based on polymorphic sequence-tagged sites. Genetics 131 (3): 609-624. PMCID: PMC1205034

Wouts W., Mráček M.Z., Gerdin S., Bedding R.A. 1982. Neoaplectana Steiner, 1929 a junior synonym of Steinernema Travassos, 1927 (Nematoda: Rhabditida). Systematic Parasitology 4 (2): 147-154. DOI: https://doi.org/10.1007/ bf00018998

Yaghoubi A., Pourjam E., Pedram M., Siddiqi M.R., Atighi M.R. 2014a. Molecular and morphological characterization of
Abursanema iranicum n. gen., n. sp. (Nematoda: Hexatylina, Sphaerularioidea) from Iran. Zootaxa 3826 (2): 301-314. DOI: https://doi.org/10.11646/zootaxa.3826.2.1

Yaghoubi A., Pourjam E., Atighi M.R., Pedram M. 2014b. Molecular and morphological characterization of Ektaphelenchoides ruehmi sp. n. (Nematoda: Ektaphelenchinae) from south-western Iran. Russian Journal of Nematology 22: 31-38.

Zhang K.Y., Liu X.H., Tan J., Wang Y., Qiao L., Yedid G., Dai C.S., Qiu R.L., Yan X.W., Tan H.W., Su Z.Y., Lai R., Gao G.F. 2012. Heterorhabditidoides rugaoensis $\mathrm{n}$. sp. (Rhabditida: Rhabditidae), a novel highly pathogenic entomopathogenic nematode member of Rhabditidae. Journal of Nematology 44: $348-360$.

Zheng J., Subbotin S.A., Waeyenberge L., Moens M. 2000. Molecular characterisation of Chinese Heterodera glycines and $H$. avenae populations based on RFLPs and sequences of rDNA-ITS regions. Russian Journal of Nematology 8: 109-113. 